\title{
Surgical procedures used for post-traumatic neurogenic bladder in a cat: report case
}

[Procedimentos cirúrgicos utilizados no tratamento da bexiga neurogênica em um gato: relato de caso]

\author{
P.T. Pavan ${ }^{1}$, V.J.V. Rossetto ${ }^{1 *}$, S.C. Rahal ${ }^{1}$, L.C. Vulcano ${ }^{1}$, J.C.S. Trindade Filho ${ }^{2}$ \\ ${ }^{1}$ Faculdade de Medicina Veterinária - UNESP - Botucatu, SP \\ ${ }^{2}$ Faculdade de Medicina - UNESP - Botucatu, SP
}

\begin{abstract}
A 1-year-old castrated crossbred male cat was referred to the Veterinary Teaching Hospital for evaluation of urinary retention associated with a subluxation at T12-T13 caused by a car accident. Urethral sphincter denervation by transection of hypogastric and pudendal nerves was performed to allow bladder emptying, but after three months post operation the cat had a urinary retention recurrence. Endoscopic urethral sphincterotomy was done resulting in urinary incontinence for four months.
\end{abstract}

Keywords: cat, urinary incontinence, urethral denervation, urethral sphincterotomy

\section{RESUMO}

Um gato de um ano de idade, macho, castrado, sem raça definida, foi encaminhado ao Hospital Veterinário Escola para avaliação de retenção urinária associada à subluxação nas vértebras T12-T13, que foi causada por um acidente automobilístico. Realizou-se a denervação do esfíncter uretral, por transecção dos nervos pudendo e hipogástrico, para permitir o esvaziamento da bexiga, porém três meses após a cirurgia inicial o animal apresentou recorrência da retenção urinária. Esfincterotomia endoscópica uretral foi então realizada, resultando em incontinência urinária por quatro meses.

Palavras-chave: gato, incontinência urinária, denervação uretral, esfincterotomia uretral

\section{INTRODUCTION}

The micturition is a conscious act of disposing urine from the urinary bladder through the urethra that requires a complex neural control system (Lorenz and Kornegay, 2004; Lees, 2005). The bladder and urethral sphincter function must be coordinated to allow the sphincter to open only during micturition and remain closed in other times (Yoshimura and Chancellor, 2004).

The neurogenic disturbances of micturition are caused by diseases or injuries of the nervous system as well as disorders of the bladder detrusor muscle, the urethral sphincter or both

Recebido em 21 de maio de 2010

Aceito em 4 de julho de 2011

*Autor para correspondência (corresponding author)

E-mail: vjvrossetto@hotmail.com
(Lorenz and Kornegay, 2004; Yoshimura and Chancellor, 2004; Lees, 2005; De Groat, 2006; Dewey, 2008). Depending on the severity and reversibility of the lesion, the functional disturbances of the micturition may be temporary or permanent (Lees, 2005; Tudury et al., 2006). The treatment of neurogenic bladder dysfunction varies according to the primary disease of the nervous system (Lees, 2005). Therefore, the aim of this report was to describe the surgical procedures performed in a cat with urinary retention after a spinal cord injury.

\section{CASE DESCRIPTION}

A 1-year-old, $4.9 \mathrm{~kg}$, castrated crossbred male cat was referred to the Veterinary Teaching Hospital for evaluation of urinary retention associated 
with a subluxation at T12-T13 caused by a car accident. According to the owner, since the accident the cat had been treated with acupuncture due to paraplegia, urinary and fecal incontinence for approximately 3 months. The treatment was interrupted and suddenly the cat developed urinary retention. On the physical examination, a distended bladder was evident during the abdominal palpation. Valsalva's maneuver for completed drainage of the bladder was not satisfactory. The neurological examination revealed paraplegia, absent cutaneous trunci reflex in the segment caudal to thoracolumbar spine, and hyperactive spinal reflexes and deep pain sensation present in both hind limbs. Neurological examination suggested thoracolumbar spine lesion.

A radiographic examination showed dorsal subluxation at T12-T13 and fracture located on the ventral margin of the T12 vertebral body. In addition, abdominal radiographic examination showed colon distended with feces and distended bladder. Complete blood cell count, and serum biochemical profile including tests for renal and hepatic function were normal. An enema was performed to remove the impacted feces, and urinary catheterization to release urine from bladder. Analysis of urine obtained by cystocentesis revealed isothenuria (specific gravity 1.036), proteinuria, occult blood, and bacteriuria.

Due to the owner's refusal to keep the cat in intermittent urethral catheterization or urethrostomy, urethral sphincter denervation was the first option treatment. After premedication with acepromazine $(0.1 \mathrm{mg} / \mathrm{kg} \mathrm{IM})$ and morphine $(0.2 \mathrm{mg} / \mathrm{kg} \mathrm{IM})$, general anesthesia was induced with propofol $(4 \mathrm{mg} / \mathrm{kg} \mathrm{IV})$, and maintained with isoflurane. The patient was positioned in dorsal recumbency and the abdomen clipped and aseptically prepared for surgery. A pre-pubic celiotomy was performed via a ventral midline approach with visualization of the bladder's neck and pelvic urethra. Bilateral hypogastric and pudendal nerves were identified and cut using an electrocautery closed to bladder and urethra (Figure 1). A routine abdominal wall closure was done. Enrofloxacin (5mg/kg BID PO) was administered postoperatively for seven days. Meloxicam $(0.1 \mathrm{mg} / \mathrm{kg}$ SID PO) and Tramadol (1mg/kg BID PO) were both administered on the day of the surgery and for five more days. One week after surgery the cat developed overflow incontinence and although less frequently, valsalva's maneuvers were still needed.

Approximately three months after surgery, the cat had recurrence of the urinary retention and hematuria. The endoscopic urethral sphincterotomy was performed as a second surgical treatment. The general anesthesia and celiotomy were performed as before. The bladder was located and isolated from surrounding viscera by packing it off with a moistened pad. Stay sutures of nylon monofilament 3-0 were placed in the apex and in the bladder's neck. A stab incision was made on the ventral aspect of the bladder, the urine was aspirated from it, and an endoscopic cysto-urethrotome (Neonate Optical Urethrotome size Fr 10; Karl Storz Endoskope, Germany) was introduced into the urethra through the bladder (Figure 2). Longitudinal urethrotomy incisions were done at 3, 6, 9 and 12 o'clock in the membranous urethra and proximal portion of penile urethra with a Sachse knife (Cold knife; Karl Storz Endoskope, Germany) including mucosa, submucosa and muscular layers. Moderated intra-operative bleeding was observed during the procedure. The cystotomy was closed with polyglactin-910 3-0 suture in a simple continuous suture pattern, and the stay sutures removed. A routine abdominal wall closure was done.

Urethral catheterization was maintained for 15 days postoperatively. Sulphamethoxazoletrimethoprim (25mg/kg SID PO) and Tramadol $(2 \mathrm{mg} / \mathrm{kg} \quad$ BID PO) were administered postoperatively for 20 days and five days, respectively. Dexametazone (0.5mg SID PO) was administered following surgery and continued for two days. Postoperative hematuria was observed for approximately 10 days. After urethral catetherization removal, a gradual improvement in urinary incontinence was observed with the reduction of residual bladder urine and by four months the animal was completely incontinent. According to the owner, after this period, the cat developed severe megacolon with fecal retention that was treated using enema by a veterinarian reference. However, the cat died 24 hours after it. At necropsy hypertrophy of the heart, and gastroenteritis cranial to an enlarged distal colon were observed. 


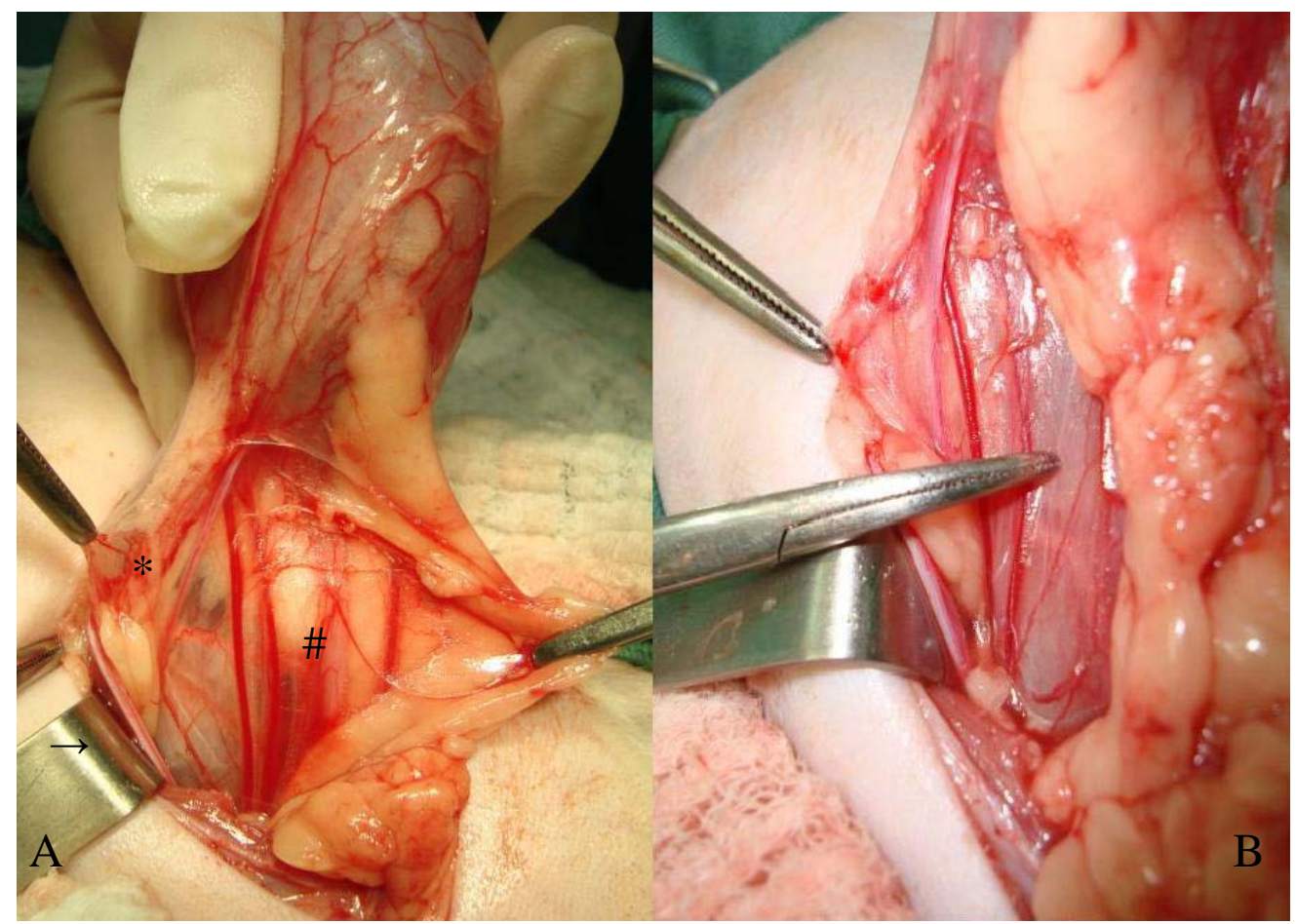

Figure 1. Cat. A) Identification of the direct hypogastric nerve after dissection of the fat adjacent to the blatter colon $(*)$. Note the deferent duct $(\rightarrow)$ and contralateral uretra (\#). B) Isolation of the left pudendal nerve, identified by styptic pliers.

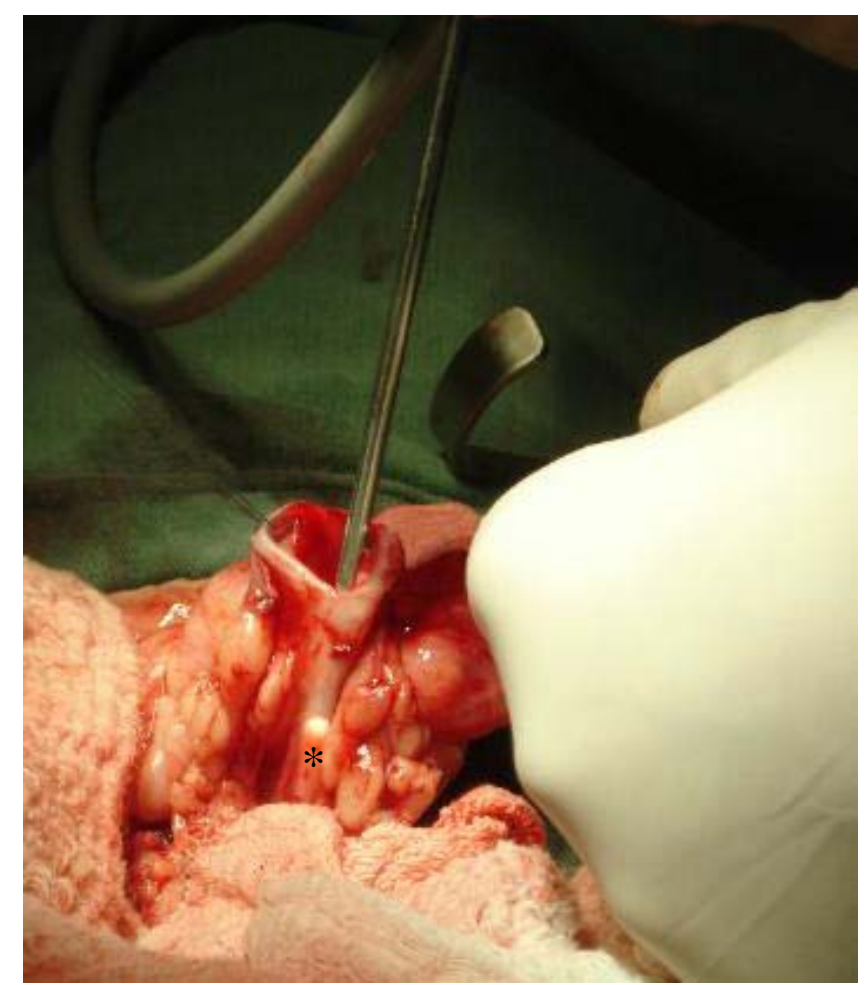

Figure 2. Cat. Introduction of the cyst-urethral endoscope cist in the direction of the urethra. Note the longitudinal incision in the filmy urethra $(*)$. 


\section{DISCUSSION}

In the present case the upper motor neuron lesion probably caused the relaxation fail of the urethral sphincter with bladder outlet obstruction and increased urine volume over time with bladder distention and an atonic detrusor muscle (De Groat, 2006). Conservative therapy of neurogenic bladder dysfunction includes emptying the urinary bladder either manually or by catheterization, measures to prevent urinary tract infections such as antibiotic treatment, and use of drugs to facilitate bladder emptying such as alpha adrenergic antagonists and skeletal muscle relaxants (Lorenz and Kornegay, 2004; Lees, 2005; Tudury et al., 2006; Windaele, 2008). However, intermittent urethral catheterization was considered unacceptable by the owner, as well as prepubic or subpubic urethrostomy techniques (Fossum et al., 2007). For this reason, another modality of surgical treatment was considered.

Among the surgical procedures described for neurogenic bladder in human patients might be cited the urethral sphincter denervation by the transection of pudendal nerves and section of the urethral sphincters through the endoscopic technique (Figueiredo et al., 1983). The denervation of the urethral sphincters reduces urethral tonus and consequently decreases the residual urine volume, preserves the function of the superior urinary tract, and allows efficient bladder emptying by manual expression (Figueiredo et al., 1983; Noll et al., 1995).

In cats, the pelvic, hypogastric and pudendal nerves are associated with the functional control of the bladder and urethra (Lorenz and Kornegay, 2004; De Groat, 2006). The pelvic nerves are responsible for parasympathetic innervation and induce detrusor muscle contraction (Dewey, 2008). The hypogastric nerves transmit sympathetic innervation to urinary bladder and internal urethral sphincter musculature and their stimulation causes detrusor muscle relaxation and internal urethral sphincter contraction (Yoshimura and Chancellor, 2004; Dewey, 2008). Pudendal nerves supply somatic innervation to striate the musculature of the external urethral sphincter and some pelvic floor muscles (Yoshimura and Chancellor, 2004; Dewey, 2008).
In the present cat, the section of hypogastric and pudendal nerves was supposed to relax the musculature of bladder's neck and distal urethra, reducing the pressure on internal and external urethral sphincters and thus permitting the urinary flow (Ali-El-Dein and Ghoneim, 2001). Additionally, the interruption of sympathetic innervations can slightly increase the frequency and amplitude of bladder contractions (Peng et al., 2006). In a report using three cats with medullar thoracic lesion and urinary retention, treated by electrosurgical denervation of the external and internal urethral sphincters, the micturition was partially restored and allowed complete bladder emptying by manual expression (Tudury et al., 2006). However, in the present case there was urinary retention recurrence. Reinnervation or permanence of complete nerve endings may cause recurrence of clinical signs (Sakamoto et al., 2000). In addition, pudendal denervation may not block completely the activity of the distal urethra because the pelvic floor muscles have influence over the urethral closure function (Ali-El-Dein and Ghoneim, 2001). The cause of recurrence was not determined in the present case. However, permanence of innervation is probably not the reason since both nerves were cut closely to the urethra.

Sphincterotomy is another useful and effective surgical therapeutic method for neurogenic bladder in human patients, especially when pharmacological treatments and intermittent catheterization have failed (Reynard et al., 2003; Ahmed et al., 2006). Longitudinal incisions in the mucosa, submucosa and muscular layer of the urethra are usually made in the area of the external urethral sphincter by an endoscopic retrograde approach from external urethral meatus (Rudd and Hendrickson, 1999; Adams, 2007). The destruction of the normal sphincter anatomy leads to the reduction of the bladder outlet obstruction, decreasing the detrusor pressure and reducing the risk of renal damage (Reynard et al., 2003).

Due to the small size of the cat, the bladder and proximal urethra were accessed by cistotomy and an endoscopic sphincterotomy was performed with an anterograde approach. The depth of the incisions is difficult to establish, but should be done until the plane of periurethral venous sinus (Reynard et al., 2003), as in the present case. 
Another difference in our technique is that we made 4 incisions at $0,3,6$ and 9 o'clock to ensure that the procedure was satisfactory. Usually most of the authors choose only one or two incisions at different points of the urethra's diameter (Fontaine et al., 1996; Reynard et al., 2003). The more frequent complications of this technique are hemorrhage, bladder neck stenosis, and erectile dysfunction (Reynard et al., 2003; Ahmed et al., 2006). Recurrence can also occur in about 8\% (Fontaine et al., 1996). In the present case moderate intra-operative bleeding that continued for approximately 10 days was observed.

Sphincterotomy failure may occur due to inadequate technique, detrusor hypocontractility, persistent urinary tract infection and urethral stricture (Reynard et al., 2003). In the present case, recurrence of urinary retention was not observed. However, megacolon was a serious complication that contributed to the cat's death. Probably an injury of autonomous nerve fibers at the time of the car accident was responsible for the extrinsic innervation of the gastrointestinal tract (Argenzio, 2004; Wood, 2007). The denervation procedure probably did not have influence, because the hypogastric nerve is responsible for maintaining the permanent tonus of internal anal sphincter (Argenzio, 2004; Wood, 2007), and the pudendal nerve is responsible for the contraction of the external anal sphincter (Argenzio, 2004; Wood, 2007). Management of post-traumatic neurogenic bladder is challenged, and new procedures to improve the quality of life should be studied.

\section{REFERENCES}

ADAMS, LG. Cystoscopy. In: ELLIOT, J.; GRAUER, G.F. BSAVA Manual of Canine and Feline Nephrology and Urology. 2nd ed. London: BSAVA, 2007. p.192-197.

AHMED; H.U.; SHERGILL, I.S.; ARYA, M. et al. Management of detrusor-external sphincter dyssynergia. Nat. Clin. Pract. Urol., v.7, p.368380, 2006.

ALI-EL-DEIN, B.; GHONEIM, M.A. Effects of selective autonomic and pudendal denervation on the urethral function and development of retention in female dogs. J. Urol., v.166, p.14551478, 2001.
ARGENZIO, R.A. General functions of gastrointestinal tract and yours control. In: REECE, W.O. Dukes' Physiology of domestic animals, 12nd ed. Cornell: Cornell University, 2004. p.353-361.

DE GROAT, W.C. Integrative control of the lower urinary tract: preclinical perspective. $\mathrm{Br}$. $J$. Pharmacol., v.147, p.25-40, 2006.

DEWEY, C.W. Neurology and neurofarmacology of normal and abnormal micturition. In: DEWEY, C.W. A practical guide to canine and feline neurology. 2nd ed. Melbourne: WileyBlackwell, 2008. p.209-214.

FIGUEIREDO, J.A.; BORELLI, M.; BRUSCHINI, H. et al. Cirurgia endoscópica na bexiga neurogênica. In: NETTO Jr., N.R. Endoscopia urológica. 1. ed. São Paulo: Roca, 1983. p.148-55.

FONTAINE, E.; HAJRI, M.; RHEIN, F. et al. Reappraisal of endoscopic sphincterotomy for post-traumatic neurogenic bladder: A prospective study. J. Urol., v.155, p.277-280, 1996.

FOSSUM, T.W.; HEDLUND, C.S.; HULSE, D.A. et al. Surgery of the bladder and urethra. In: FOSSUM, T.W. et al. Small Animal Surgery. 3nd ed. St Louis: Mosby Elsevier, 2007. p.663701.

LEES, G.E. Incontinence, enuresis, dysuria and nocturia. In: ETTINGER, S.J.; FELDMAN, E.C. Textbook of veterinary internal medicine. 6nd ed. Philadelphia: Saunders, 2005. p.93-96.

LORENZ, M.D.; KORNEGAY, J.N. Disorders of micturition. In: LORENZ, M.D.; KORNEGAY, J.N. Handbook of veterinary neurology. 4nd ed. Philadelphia: Saunders, 2004. p.75-90.

NOLL, F.; SAUERWEIN, D.; STOHRER, M. Transurethral sphincterotomy in quadriplegic patients: long-term-follow-up. Neurourol. Urodyn., v.14, p.351-358, 1995.

PENG, C.; CHEN, J.J.; CHANG, H. et al. External urethral sphincter activity in a rat model of pudendal nerve injury. Neurourol. Urodyn., v.25, p.388-396, 2006.

REYNARD, J.M.; VASS, J.; SULLIVAN, M.E. et al. Sphincterotomy and the treatment of detrusor-sphincter dyssynergia: current status, future prospects. Spinal Cord, v.41, p.1-11, 2003. 
RUDD, R.G.; HENDRICKSON, D.A. Minimally invasive surgery of the urinary system. In: FREEMANM, L. J. Veterinary Endosurgery, 1nd ed. St. Louis: CV Mosby, 1999. p.226-235.

SAKAMOTO, K.; SMITH, G.M.; STORER, P.D. et al. Neuroregeneration and voiding behavior patterns after pudendal nerve crush in female rats. Neurourol. Urodyn., v.19, p.311321, 2000.

TUDURY, E.A.; BARAÚNA, D.; CHIORATTO $\mathrm{R}$. et al. Urethral sphincters denervation by prepubic celiotomy in three paraplegic cats. Clin. Vet., v.60, p.54-58, 2006.
WOOD, J.D. Neuropathophysiology of functional gastrointestinal disorders. World $J$. Gastroenterol., v.13, p.1313-1332, 2007.

WYNDAELE, J.J. Conservative treatment of patients with neurogenic bladder. Eur. Urol., v.7, p.557-565, 2008.

YOSHIMURA, N.; CHANCELLOR, M.B. Differential diagnosis and treatment of impaired bladder emptying. Rev. Urol., v.6, p.24-31, 2004. 